\title{
The feasibility study on trapping experiments with lights in Barito river of Indonesia
}

\author{
Ahmadi * \\ Faculty of Marine and Fisheries, Lambung Mangkurat University, Banjarmasin, Indonesia
}

\author{
Index Terms \\ Barito River \\ Incandescent Light \\ LED Light \\ Macrobrachium $S p$ \\ Traps
}

Received: 19 September 2017

Accepted: 13 November 2017

Published: 4 December 2017

\begin{abstract}
This study provides scientific evidence on the catchability of low-powered incandescent light and LED light traps in catching crustaceans and fish from highly turbid water in Barito River, South Kalimantan. The experimental conditions encompassed highly turbid water, slow flowing, blocked water, and rarely vegetated habitat with water depths ranging from 2 to $4 \mathrm{~m}$. The traps used were collapsible box-shaped trap, wire-square trap, acrylic-square trap, PVC box-shaped trap, wire fish trap, bamboo fish trap and minnow nets. The light traps were deployed randomly with an interval distance of $2.5 \mathrm{~m}$ using 1-night soaking time. Light traps sampling accounted for 343 shrimps ( 1 family), 53 fishes ( 6 families) and 2 crabs ( 1 family). The catches were dominated by Macrobrachium $s p(98.54 \%)$ and Glossogobius giuris (36.54\%). Collapsible trap fishing with incandescent lights was as effective at sampling as wire square trap fishing with LED lights. The minnow nets were excellent in catching shrimp and fish as compared with PVC box-shaped trap and wire/bamboo fish traps. Colour of light had strong effects on the number of shrimp and fish collected. For future applications in using LED light for trap fishing, a more comprehensive study on its efficiency for catching juveniles of target and non-target species is strongly recommended.
\end{abstract}

(C) 2017 The Author(s). Published by TAF Publishing.

\section{INTRODUCTION}

South Kalimantan is one of the five provinces in Kalimantan (formerly called Borneo) with the capital city of Banjarmasin. It is bordered with East Kalimantan at the north, with Makassar Strait at the east, with Java Sea at the south and with West Kalimantan and Central Kalimantan at the west. South Kalimantan is also often known as Province with a thousand-river where the Barito River is the largest and the longest river in Indonesia, more than $6.000 \mathrm{~km}$ long. The Barito River allows for transportation, drinking water sources, floating market and fisheries, among others.

A number of researches has been addressed to explore the characteristic habitats and fish species in Barito River $[1,2,3]$ the abundance and diversity of typical plankton [4] and fishing activities in the river $[5,6,7,8,9,10]$.

Several active and passive fishing gears are being used to collect fish and shrimp from Barito River e.g., hook and line, gill net, lift net and traps, among others. In the past, a total of 350 species was found in this river, but now it is estimated only about 150 species [11]. Some important fish species like Arowana (Scleropages formosus), clown knifefish (Notopterus chitala), mad barb (Leptobarbus hoevenii) and the greater bony lipped barb (Osteocheilus melanopleura) seemed to disappear from the river. They are extremely vulnerable to the destructive fishing as well as water pollution from plywood industry and dockyard. Therefore, fishing technology development that is environmentally friendly and efficient, should be promoted. The use of lights would be a promising option for responsible fishing practices.

Light trap is one of the good examples for collecting many species of different habitats when other fishing gears like towed net are not useful $[12,13]$. In many cases, light traps typically use battery-powered incandescent bulbs, chemical light stick, blacklight fluorescent Ultra Violet (UV) or electrical lamps, while the use of LEDs has

\footnotetext{
* Corresponding author: Ahmadi

†Email: ahmadi@unlam.ac.id
} 
not much been performed under field condition. As for the difference in light sources, each lamp has its unique optics and intensity output even with same electrical power use.

There was no scientifically published information on the use of light traps in Barito River, so far. Therefore, before light traps can be used quantitatively, several potential biases have to be considered. How effective are the light traps used in high turbidity of the river? What species will be sampled by the light traps? Are individual species collected in different numbers using specific colors/relative intensities of light? Do size and shape of the light trap affect number of catch? We performed this study to address these questions by extracting the sampling data collected from the Barito River. The information obtained may be useful for commercial or breeding purposes of extinct and endangered species as well as for fisheries management.

\section{MATERIALS AND METHODS}

\section{A. Study Site}

Trapping experiments with lights were carried out in Barito River of South Kalimantan Province, located on $03^{\circ} 19^{\prime} 012^{\prime \prime S} 114^{\circ} 34^{\prime} 098^{\prime \prime} \mathrm{E}$ and $03^{\circ} 20^{\prime} 665^{\prime \prime S}$ $114^{\circ} 36^{\prime} 296^{\prime \prime}$ E determined with the GPS 60 (Garmin Co. Ltd., Taiwan). The experimental conditions encompassed highly turbid water (total suspended solids ranged from 182-567 $\mathrm{mgl}^{-1}$ ), slow flowing, blocked water, and rarely vegetated habitat with water depths from $2-4 \mathrm{~m}$. The transparency of water varied from 45 to $55 \mathrm{~cm}$ (Secchi-disk reading at noon). The surface water temperature was recorded daily and ranged from 27 to $29^{\circ} \mathrm{C}$ throughout the trials.

\section{B. Experimental Design}

Experiment 1: Collapsible trap fishing with different light intensities of incandescent lamps. The four collapsible boxshaped traps were constructed with iron rod frame $(80 \times 60$ $\times 28 \mathrm{~cm}$ ), covered with polyethylene netting and had two 58 $\mathrm{cm}$ slit all-web entrances at the ends (Kagotoku Shiroyama Kenmousha, Ise, Japan). Each of the four traps had one incandescent lamp. The lamps used were (i) Japanese squid fishing tackles (Yo-zuri Co. Ltd. Japan) consisting of SIL-1 $(10 \times 3 \mathrm{~cm} ; 0.45 \mathrm{~W})$ and SIL-2 $(16 \times 3 \mathrm{~cm} ; 0.9 \mathrm{~W})$ powered by 1.5 and $3.0 \mathrm{~V}$ dry-cell batteries respectively, and, (ii) acrylic box-shaped lamps consisting of DIM and LIGHT, of which a $4.5 \mathrm{~W}$ lamp was placed inside a waterproof acrylic box (14 $\times 8 \times 15 \mathrm{~cm}$ ) generated by $6 \mathrm{~V}$ dry-cell batteries. For DIM, the walls of the box were lined with a white-paper. Light intensity of each lamp was 215 lx (SIL-1), 398 lx (SIL-2), $1010 \mathrm{~lx}$ (DIM) and $2050 \mathrm{~lx}$ (LIGHT) determined in air using an illuminometer (IM-2D, Topcon, Ltd. Tokyo).

Experiment 2: Collapsible trap fishing with different coloured incandescent or LED lamps. Five collapsible boxshaped traps were modified in their funnel entrances by replacing the two slit all-web entrances at the ends with two open slackness nylon monofilaments $23 \mathrm{~mm}$ mesh size. Additional net bag was placed at the bottom of the trap to prevent juveniles from dropping. Each of the five traps was assigned with one colour of LED Torpedo flashers $(24 \times 5$ $\mathrm{cm}$, Yuli Co. Ltd. China) or one colour of incandescent lamps YL/YS-1 (22 $55 \mathrm{~cm}$, Yuli Co. Ltd. China), consisting of blue, green, yellow, red and extra white.

Experiment 3: Wire-square trap fishing with different coloured LED lamps. Five wire-square traps were made of iron-wire frame $(25 \times 25 \times 22 \mathrm{~cm})$, covered with black $3 / 5$ inch hexagonal mesh wire (16 gauge PVC-coated wire), and had four entry funnels located on each side with a 5 $\mathrm{cm}$ inside ring entrance. A trap door on top $(23 \times 24 \mathrm{~cm})$ was used to release the catches. Each of the five traps was assigned with one colour of LEDs. Each colour (blue, green, yellow, red and extra white) was placed inside the Squid Lamp case (SIL-2) powered by $3 \mathrm{~V}$ dry-cell batteries $(0.06$ $W$ ). Light intensity of LEDs was set at equal quanta intensities by placing a grey fibreglass window screen (Dio Chemicals, Ltd., Tokyo) inside of the lamp to standardize the lights used.

Experiment 4: The acrylic-square trap fishing with different coloured LED lamps for sampling juvenile species. Five acrylic-square traps were constructed with 3-mm acrylic plates and had 8 entrance slits with $1 \mathrm{~cm}$ wide opening on each side. The acrylic plates were attached vertically with two sheets of PVC $(24 \times 24 \mathrm{~cm})$ top-down and reinforced with four iron rods ( $25 \mathrm{~cm}$ long) on each corner. The trap was equipped with two floats at the surface, four wirestairways $(23 \times 23 \mathrm{~cm})$ attached to lower part of PVC sheet on each side and a collection wire-jar at the bottom $(18 \times$ $18 \times 7 \mathrm{~cm}$ ). A lamp was placed downright in the middle of trap. Each of the five traps was assigned with one colour of LEDs following the same procedure in Experiment 1.

Experiment 5: Various fishing traps with the white LED and incandescent lamps. Four traps with different sizes and shapes were investigated. These traps were: (1) PVC 
box-shaped trap: PVC rod frame $(67 \times 53 \times 20 \mathrm{~cm})$ covered with black $150 \mathrm{~mm}$ hexagonal mesh wire (16 gauge PVCcoated wires); ten entry funnels are located on each side of the trap with a $5.2 \mathrm{~cm}$ inside ring entrance; (2) Wire fish trap: heart-shaped, $45 \mathrm{~cm}$ high and $40 \mathrm{~cm}$ wide, with $1.2 \mathrm{~cm}$ square mesh wire and $2.5 \mathrm{~cm}$ wide opening of entrance slit; (3) Bamboo fish trap: heart-shaped, $42 \mathrm{~cm}$ high and $30 \mathrm{~cm}$ wide with horizontal gap $1.5 \mathrm{~cm}$ and $2.5 \mathrm{~cm}$ wide opening of entrance slit; and (4) Minnow nets: cylindrical-shaped, $60 \mathrm{~cm}$ long by $30 \mathrm{~cm}$ wide, covered with $1.3 \mathrm{~cm}$ polyethylene netting and $7 \mathrm{~cm}$ inside the ring entrance. Each of the four traps was associated with $0.06 \mathrm{~W}$ white LED or $1.5 \mathrm{~W}$ incandescent squid fishing lamp (SIL-2; Experiment 1).

TABLE 1

SPECIFICATION OF TRAPS AND LAMPS USED FOR THE TRAPPING EXPERIMENTS IN BARITO RIVER

\begin{tabular}{|c|c|c|c|c|}
\hline Exp. & Type of Trap and Lamp & $\#$ & Material & Size \\
\hline \multirow[t]{5}{*}{ Experiment 1} & Collapsible box-shaped trap & 4 & $\begin{array}{l}\text { Iron rod frame covered with } \\
\text { polyethylene netting }\end{array}$ & $80 \times 60 \times 28 \mathrm{~cm}$ \\
\hline & - SIL-1 & 1 & Glass & $10 \times 3 \mathrm{~cm}$ \\
\hline & - SIL-2 & 1 & Glass & $16 \times 3 \mathrm{~cm}$ \\
\hline & - DIM & 1 & Acrylic & $14 \times 8 \times 15 \mathrm{~cm}$ \\
\hline & - LIGHT & 1 & Acrylic & $14 \times 8 \times 15 \mathrm{~cm}$ \\
\hline \multirow[t]{3}{*}{ Experiment 2} & Modified collapsible box-shaped trap: & 10 & $\begin{array}{l}\text { Iron rod frame covered with } \\
\text { polyethylene netting, and nylon } \\
\text { monofilaments } 23 \mathrm{~mm} \text { mesh size }\end{array}$ & $80 \times 60 \times 28 \mathrm{~cm}$ \\
\hline & - LED Torpedo flasher & 5 & Plastic & $24 \times 5 \mathrm{~cm}$ \\
\hline & - Colour incandescent YL/YS-1 & 5 & Plastic & $22 \times 5 \mathrm{~cm}$ \\
\hline \multirow[t]{2}{*}{ Expermient 3} & Wire square trap & 5 & $\begin{array}{l}\text { Iron-wire frame covered with } \\
\text { black } 150 \mathrm{~mm} \text { hexagonal mesh wire }\end{array}$ & $25 \times 25 \times 22 \mathrm{~cm}$ \\
\hline & - SIL-2 & 5 & Glass & $16 \times 3 \mathrm{~cm}$ \\
\hline \multirow[t]{2}{*}{ Expermient 4} & Acrylic square trap & 5 & Acrylic & $24 \times 24 \times 23 \mathrm{~cm}$ \\
\hline & - SIL-2 & 5 & Glass & $16 \times 3 \mathrm{~cm}$ \\
\hline \multirow[t]{6}{*}{ Expermient 5} & PVC box-shaped trap & 2 & $\begin{array}{l}\text { PVC rod frame covered with black } \\
150 \mathrm{~mm} \text { hexagonal mesh wire }\end{array}$ & $67 \times 53 \times 20 \mathrm{~cm}$ \\
\hline & Wire fish trap & 2 & Wire & $45 \times 40 \mathrm{~cm}$ \\
\hline & Bamboo fish trap & 2 & Bamboo & $42 \times 30 \mathrm{~cm}$ \\
\hline & Minnow nets & 2 & Polyethylene netting & $60 \times 30 \mathrm{~cm}$ \\
\hline & - White LED light (SIL-2) & 4 & Glass & $16 \times 3 \mathrm{~cm}$ \\
\hline & - Incandescent (SIL-2) & 4 & Glass & $16 \times 3 \mathrm{~cm}$ \\
\hline
\end{tabular}

The specifications of traps and lamps used are summarized in Table 1 and shown in Figure 1. The light traps with constant light pattern were deployed randomly at the bottom of the riverbank and illumination began $1 \mathrm{~h}$ before sunset and retrieved the next morning. On each sampling date, each trap was separated from the others about 2.5 $\mathrm{m}$ to minimize any significant light contamination between traps. Such trap arrangement was considered sufficient for the existing turbidity conditions and illumination intensities. Each experimental group was repeatedly used for 6-night fishing. The trials consisted of 113-trap hauls/lamp type using 1-night soaking time, which varied from 14-16 hours. After retrieval, the catches were counted and identified for species and sex, and measured for total length and weigh. 


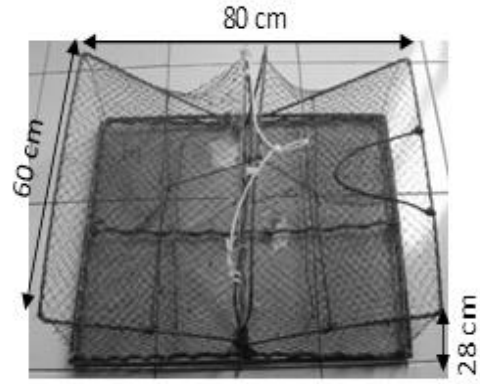

Collapsible box shaped trap

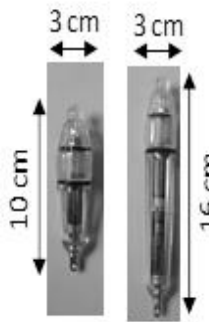

SIL-1 SIL-2

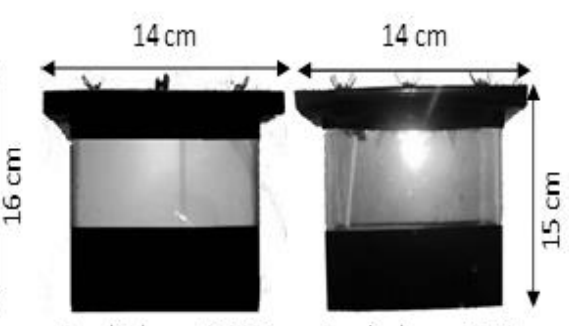

Acrylic lamp: LIGHT Acrylic lamp: DIM

Experiment 1

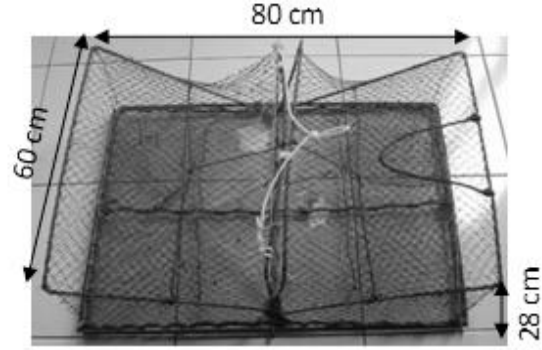

Collapsible box shaped trap

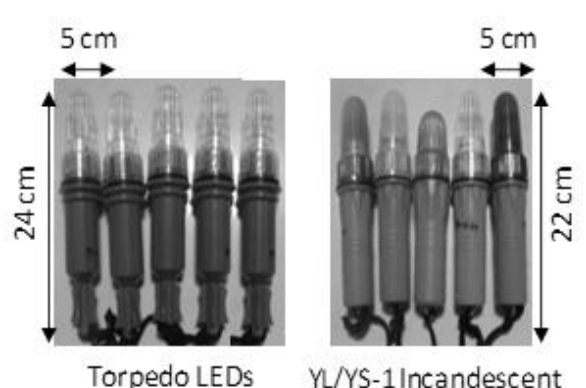

Torpedo LEDs YL/YS-1Incandescent

Experiment 2

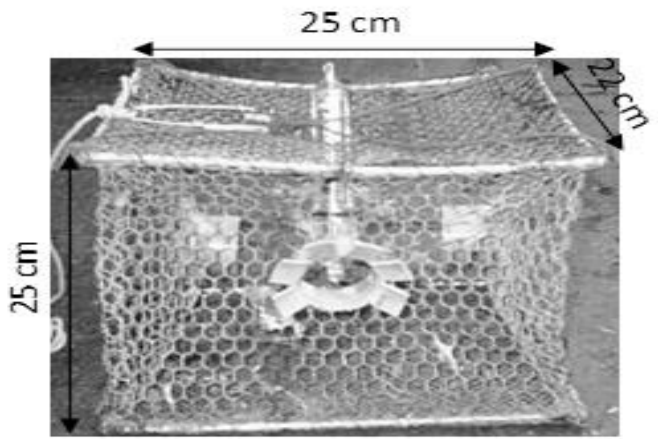

Wire-square trap

Experiment 3

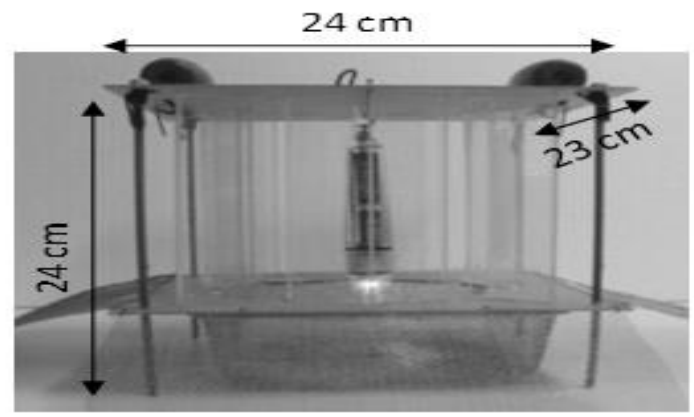

Acrylic-square trap

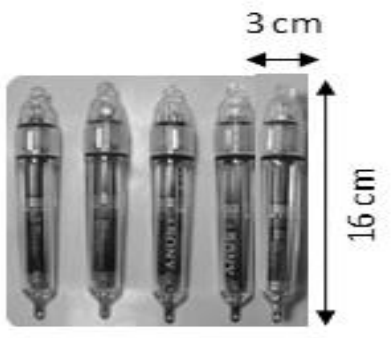

Squids LED SIL-2

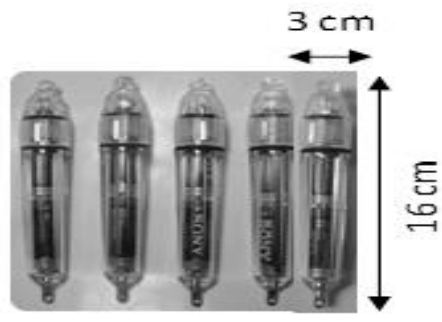

Squids LED SIL-2

Experiment 4 


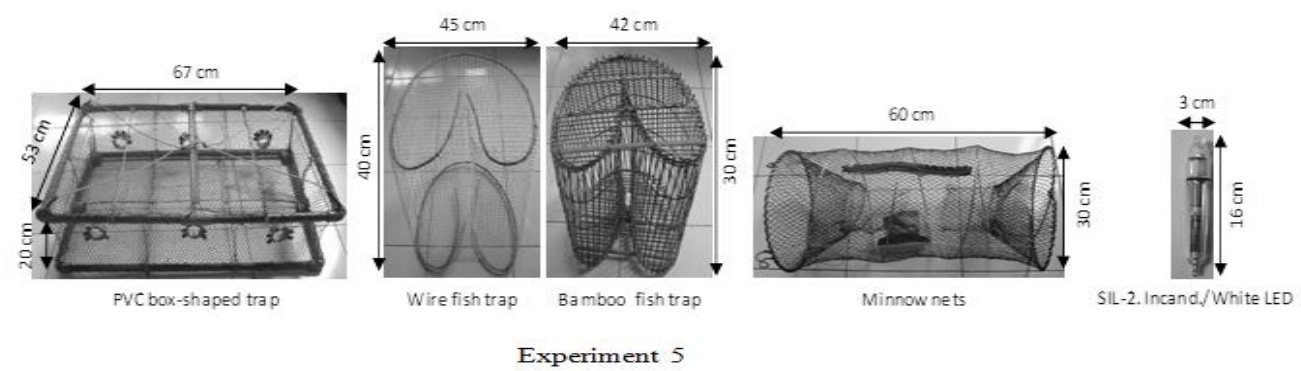

Fig. 1. The traps and lamps used during the trapping experiments in Barito River

\section{Statistical Analysis}

Mann-Whitney test was used to determine which catch differed between incandescent and LED light traps. Kruskal-Wallis test was used to investigate if there were significant differences in the total catches of the four or five different trapping treatments. A post-hoc analysis test was performed using the Multiple Comparison to see which catch differed significantly among the traps [14]. All tests were evaluated at the 0.05 level of significance.

\section{RESULTS}

From a series of trapping experiments, we collected 343 shrimps ( 1 family), 53 fishe ( 6 families), and 2 crabs (1 family) as presented in Table 2. There was a large variability in the number of catch between shrimp and fish. The shrimp consisted of $98.54 \%$ long arms shrimp
(Macrobrachium sp.) 24-85 mm TL and $1.46 \%$ giant river prawn (M. rosenbergii) 71-75 $\mathrm{mm}$ TL belonging to family Palaemonidae. The fish comprised of $36.54 \%$ tank goby (Glossogobius giuris) from family Gobiidae, $34.62 \%$ sinuous gudgeon (Oxyeleotris urophthalmus) $11.54 \%$ marble gudgeon (Oxyeleotris marmorata) from family Eleotridae, $5.77 \%$ flatfish (Flounder pleuronectes) from family Pleuronectidae, $3.85 \%$ spotted fire eel (Mastacembelus erythrotaenia) from family Mastacembelidae, $3.85 \%$ Bulu barb (Puntioplites bulu) and $1.92 \%$ greater bony lipped barb (Osteochilus melanopleura) from family Cyprinidae, and $1.92 \%$ long whiskers catfish (Mystus gulio) from family Bagridae, with the sizes ranged of 60-310 mm TL and 4-177 g weight. In addition, we also collected two paddy field's crab (Parathelphusa convexa) belonging to family Parathelphusidae. The size-frequencies of catches are illustrated in the relationship between total length and weight (Figure 2).

TABLE 2

SPECIFICATION OF TRAPS AND LAMPS USED FOR THE TRAPPING EXPERIMENTS IN BARITO RIVER

\begin{tabular}{llll}
\hline \hline English Name & Family & Species & Catch \\
\hline Shrimp: & & & 343 \\
Giant freshwater shrimp & Palaemonidae & Macrobrachium rosenbergii & 5 \\
Longarms shrimp & Palaemonidae & Macrobrachium sp & 338 \\
Fish: & & & 53 \\
Tank Goby & Gobiidae & Glossogobius giuris & 19 \\
Sinuous gudgeon & Eleotridae & Oxyeoleotris urophthalmus & 18 \\
Marbled gudgeon & Eleotridae & Oxyeoleotris marmorata & 6 \\
Flatfish & Pleuronectidae & Flounder pleuronectes & 3 \\
Spotted fire eel & Mastacembelidae & Mastacembelus erythrotaenia & 2 \\
Bulu barb & Cyprinidae & Puntioplites bulu & 2 \\
Greater bony lipped barb & Cyprinidae & Osteochilus melanopleura & 1 \\
Long whiskers catfish & Bagridae & Mystus gulio & 1 \\
Crab: & & & 2 \\
Paddyfield's crab & Parathelphusidae & Parathelphusa convexa & 2 \\
\hline \hline
\end{tabular}


The trials with the collapsible box-shaped traps containing different light intensities of incandescent lamps in Experiment 1 showed that there were no significant differences in the total number of catches among the four traps (Kruskal-Wallis test, $H=2.839, p>0.05$ ). Overall, the traps had some success in catching Macrobrachium sp. (total 39), Glossogobius giuris (5), Mystus gulio (1) and Mastacembelus erythrotaenia (1). In this trial, the LIGHT and DIM traps caught the same number of Macrobrachium sp (13). The average weight of catches was $10.52 \pm 17.44 \mathrm{~g}(M \pm S D)$.

The five collapsible box-shaped fishing traps with different coloured incandescent or LED lamps in Experiment 2 demonstrated that the colour of lights had strong effects on the number of shrimp and fish collected especially Macrobrachium sp and Glossogobius giuris. Quantitatively, LED light traps were more effective in catching $\mathrm{Mac}$ robrachium sp (total 138) than incandescent light traps (total 51) (Mann-Whitney test, $T=1.412, p<0.05$ ).

The average weight of catches for incandescent light traps and LED light traps was $5.22 \pm 11.64 \mathrm{~g}$ and 5.32 $\pm 13.17 \mathrm{~g}$ respectively. Furthermore, sex ratio of Macrobrachium sp was 1:2.3 (male:female). We collected 48 eggbearing females during the whole sampling period. From the length measurement, the male chelae were 1.5 times as long as its total length and 1.3 times as long as the females of the same body size.

The results of Experiment 3 showed that there were no significant differences in the total number of catches among the five wire-square traps with different coloured LED lamps (Kruskal-Wallis test, $H=3.095, p>0.05$ ). The shrimp was dominated by Macrobrachium sp. (total 66), while the fish was represented by Oxyeleotris urophthalmus (10). The least number of catch was Glossogobius giuris (1) caught by red trap. The average weight of the catches was $7.84 \pm 9.11 \mathrm{~g}$.

The trials with the five acrylic-square traps containing different coloured LED lamps in the Experiment 4 displayed that the traps had no success in catching both fish and shrimp juveniles. The only three juveniles of Macrobrachium $s p$ were collected from the blue and yellow light traps due to the considerable breakage on the entrance slits of traps which allowed the animals to escape from the traps. The average weight of the catches was $2.27 \pm 2.37 \mathrm{~g}$.

The performance of PVC box-shaped trap, wire fish trap, bamboo fish trap, and minnow nets associated with incandescent lamp (SIL-2) or white LED was examined in Experiment 5. There were no significant differences in the total catch among the four traps (Kruskal-Wallis test, HLED
$=6.889, \mathrm{HINC}=4.286, p>0.05)$. Overall, the minnow nets were most effective among the traps (total 20 for incandescent light trap and 14 for LED light trap) especially for catching Macrobrachium sp. The other traps collected less number of catches for all trials. The average weight of catches for incandescent light traps and LED light traps was $7.15 \pm$ $8.63 \mathrm{~g}$ and $7.33 \pm 8.02 \mathrm{~g}$ respectively. The detailed data on the number of catches on each experiment can be seen in Table 3.

The average weight of catches for incandescent light traps and LED light traps was $5.22 \pm 11.64 \mathrm{~g}$ and 5.32 $\pm 13.17 \mathrm{~g}$ respectively. Furthermore, sex ratio of Macrobrachium sp was 1:2.3 (male:female). We collected 48 eggbearing females during the whole sampling period. From the length measurement, the male chelae were 1.5 times as long as theirs total length and 1.3 times as long as the females of the same body size.

\section{DISCUSSION}

The present study clearly demonstrates that trapping with low-powered underwater lamps is adaptable and applicable in turbid water of Barito River. Data on phototactic response showed that the selected colours or relative light intensity of incandescent and LED lamps used in this study had strong effects on the number of catches sampled, where LED light traps are outperformed to the incandescent ones.

A total of 11 species belonging to 8 families was sampled from Barito River. Prior to this study, some researchers carried out surveys to inventory fish species living in this river, for example, [1] documented as 47 fish species belonging to 8 families, while Prasetyo et al. [2] currently reported that there are 104 fish species comprised of $23 \mathrm{fam}$ ilies found in this river. Most of them were collected from Sembujur River, a tributary of Barito River. The present study is a good starting point in view of commercial purposes where yellow and red LED light traps are likely effective in catching M. rosenbergii, whereas white LED light traps are more effective in catching Oxyeleotris marmorata. This provides an alternative for fishers to use light traps since baited traps or hook and lines are not considered useful. Since the catch sizes of both species were smaller than marketable size, this could mean that in order to capture more large sized species, the construction and size of light traps should be improved, performance of underwater lamps should be refined, the fishing area should be extended, and experimental designs should be developed with different methods.Other fish species like Osteochilus 
melanopleura could be targeted for breeding purposes. This study tried to collect the information on the catch efficiency of the tested light traps with no specific species to be tar- geted, so the issues on by-catch were not discussed in this study.

TABLE 3

SPECIFICATION OF TRAPS AND LAMPS USED FOR THE TRAPPING EXPERIMENTS IN BARITO RIVER

\begin{tabular}{lllc}
\hline \hline English Name & Family & Species & Catch \\
\hline Shrimp & & & 343 \\
Giant freshwater shrimp & Palaemonidae & Macrobrachium rosenbergii & 5 \\
Longarms shrimp & Palaemonidae & Macrobrachium sp & 338 \\
Fish & & & 53 \\
Tank Goby & Gobiidae & Glossogobius giuris & 19 \\
Sinuous gudgeon & Eleotridae & Oxyeoleotris urophthalmus & 18 \\
Marbled gudgeon & Eleotridae & Oxyeoleotris marmorata & 6 \\
Flatfish & Pleuronectidae & Flounder pleuronectes & 3 \\
Spotted fire eel & Mastacembelidae & Mastacembelus erythrotaenia & 2 \\
Bulu barb & Cyprinidae & Puntioplites bulu & 2 \\
Greater bony lipped barb & Cyprinidae & Osteochilus melanopleura & 1 \\
Long whiskers catfish & Bagridae & Mystus gulio & 1 \\
Crab: & & & 2 \\
Paddyfield's crab & Parathelphusidae & Parathelphusa convexa & 2 \\
\hline \hline
\end{tabular}

In our observation, Macrobrachium sp were abundantly found in this river and showed stronger phototactic response than $M$. rosenbergii [15] of the same genus. Size frequencies of Macrobrachium sp collected (24-85 mm) indicated that the light traps caught juveniles and adults exclusively. They could be considered as a multichromatic species because of showing photopositivite for all colours. In this study, many more females were captured than males in all type traps with the sex ratio of $1.7: 1$. About $40 \%$ of total females caught by light traps were the egg-bearing females. In many cases, females carrying the eggs are usually inactive during the breeding season and are not attracted to food or bait $[16,17,18]$. However, the light traps can do. Macrobrachium sp in this river morphologically resembles with species M. australiense [19] from Australia River [20].

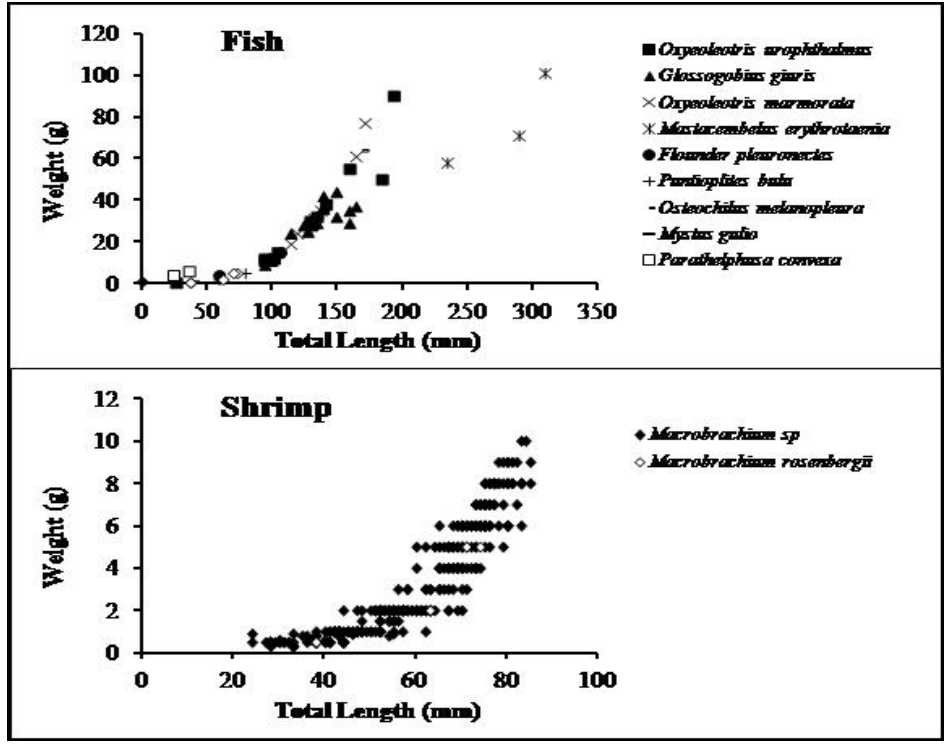

Fig. 2 . Total length and weight showing size-frequencies of fish (top) and shrimp (bottom) 
For differentiating between two species, cheliped traits were considered as they show a high level of developmental variation [21]. It was clear from our findings that the male's chelae of Macrobrachium sp (112 mm long) is twice longer than that of M. Australiense ( $51 \mathrm{~mm}$ ) as described by Short [21], at the same body size (72 $\mathrm{mm})$. It is a great challenge to provide correct identification of Macrobrachium sp including detailed information on their spawning season, distribution, growth and production wherever possible since it has not been scientifically reported.

The optical characteristic of a lamp is one of the important components in designing a light trap and critical to success in fishing operation. A simple form of acrylic box-shaped lamp with all directional luminous (see Experiment 1) was manually made and successfully used to capture American crayfish (Procambarus clarkii) from a pond in Japan [22]. Another light source as incandescent squid fishing tackle (e.g. SIL-1, $0.45 \mathrm{~W}$ ) with diamond shape in its surface was able to increase the distribution of the amount of lights and showed to be equally effective to the acrylic box-shaped lamps (DIM/LIGHT, 4.5 W). The SIL-1 or SIL-2 seemed to be more effective when operated in clear water than turbid water. Whenever they are applied in turbid water the use of higher intensities is recommended and the results are still open for discussion.

Acrylic-square light traps were only used for one day fishing due to impracticability during its operation (Experiment 4). As a result, the traps caught a negligible number of juvenile shrimp and no fish was caught. The acrylic entrance slits apart from the trap body because of loss of adhesiveness when soaked and from water pressure. Acrylicsquare light trap was initially tested in indoor tank belonging to the Faculty of Fishery, Kagoshima University Japan and had some success in catching the juvenile of $P$. clarkii during recapture experiment. We used the trap to describe their exploratory behaviour under light-adapted conditions, and explored to collect them from a pond (unpubl. data). A redesign of the current acrylic-square light trap may increase the function of catch efficiency in Barito River.

The results also clearly demonstrated that traps with different sizes and shapes but containing the same amount of attractant had an effect on the numbers caught as shown in Experiment 5. Comparative trapping with incandescent lamps or LED lamps revealed that minnow nets were excellent in catching shrimp and fish as compared to that of PVC box-shaped trap, wire-fish trap, and bamboo fish trap. This is because the minnow nets had a cylindrical shape and are easily rolled on to the riverbed, thus allowing the ani- mals to easily find the funnel entrances. Whereas for square or oval type traps, their positions could easily change due to the bottom current resulting in animals not being able to find the funnel entrance. For bamboo fish traps, a critical issue was found on the bamboo-aperture itself, which were approx. $15 \mathrm{~mm}$ wide which made it possible for animals inside the trap to escape. Thus, to be able to catch more, the construction and size of bamboo fish trap should be modified and stabilized with weights when in operation. The catches cannot be standardized to the Catch Per Unit of Effort (CPUE) for all treatments because soaking period of the lights during operation was variable and dependent on the type of light devices and variance in battery life. For instance, SIL-1 (0.45 W, $1.5 \mathrm{~V}$ ) in Experiment 1 would frequently turn off compared to others. Under such condition, the calculated CPUE for SIL-1 at approximately $10 \mathrm{~h}$ of immersion was 0.65 and for LIGHT $(4.5 \mathrm{~W}, 6 \mathrm{~V})$ at $16 \mathrm{~h}$ of immersion was 1.41. For future applications, the use of LEDs is considered more advantageous than incandescent bulbs, because they are more energy-efficient, have more colours available, and are more durable. The main challenge for designing light traps is how to create a waterproof electrical light source at reasonable cost and adaptable into different depths of waters.

\section{CONCLUSION}

This study provides scientific information on the catchability of low-powered incandescent light and LED light traps in catching crustacean and fish from highly turbid water in Barito River. Collapsible fish traps with incandescent lights were as effective at sampling as wire square trap with LED lights. The use of minnow nets was an excellent way of catching shrimp/fish as compared to PVC box shaped trap and wire/bamboo fish traps. Colour of light had strong effects on the number of shrimp/fish collected. For future applications of using LED light for trap fishing, a more comprehensive study on its efficiency for catching juvenile of target and non-target species is strongly recommended.

\section{ACKNOWLEDGMENT}

This research was under our own means of funding. The authors are grateful to Mr. Yusuf and Ahmad Rizani for their assistance during the trapping activities and to Mrs. Siti Ubaidah and Mrs. Tien Zubaidah for resultant measurements. 


\section{REFERENCES}

[1] K. MacKinnon, "The ecology of kalimantan," Clarendon, VA: Periplus Editions, 1996.

[2] D. Prasetyo, C. Asyari and A. Sudrajat, "Inventory of fish species and habitat characteristics of Barito River waters, South Kalimantan and Central Kalimantan," 2005. [Online]. Available: goo.gl/KjxnV

[3] Asyari, "Characteristic of habitat and fish species at some fishery sanctuaries in the stream of Barito river, south Kalimantan," Indonesian Journal of Fisheries and Aquatic Sciences, vol. 4, no. 13, pp. 155-163, 2006.

[4] A. Rahman, "Study on abundance and diversity of typical planktons at estuary river of Kelayan," Al 'Ulum, vol. 3, no. 6, pp. 1-6, 2008.

[5] A. D. Utomo, S. Rupawan and S. Suryaningrat, "Fishing activities in river Barito of south Kalimantan and central Kalimantan," in Proceedings of the Research Results, Jakarta, Indonesia, 2003.

[6] A.D. Utomo and D. Prasetyo, "Catch evaluation of several fishing activities at Barito river, South Kalimantan and central Kalimantan," Journal of Indonesian Fisheries Research, vol. 11, no. 2, pp. 1-22, 2005.

[7] D. Prasetyo, "Inventory of fish species on Sembujur river waters, south Kalimantan," in Proceeding of Indonesian Fisheries National Seminar, Jakarta Fisheries University, Jakarta, Indonesia, 2005.

[8] Rupawan, "Specification, operational way and gear selectivity of gillnet on Barito River," in Proceeding of $\mathrm{Na}$ tional Seminar, the third Indonesian Inland Fishery Forum, Palembang, Indonesia, 2006.

[9] A. D. Utomo and Asyari, "The fishing gears selectivity at Barito River, South Kalimantan and Central Kalimantan," in Proceeding of National Seminar, the fourth Indonesian Inland Fishery Forum, Palembang, Indonesia, 2007.

[10] N. Maneechot, W. Supiwong and A. Tanomtong, "Chromosomal analysis and Nors polymorphism of bagarius suchus (Siluriformes: Sisoridae) by conventional banding and fish techniques," Journal of Applied and Physical Sciences, vol. 2, no. 1. pp. 10-19, 2016.

DOI: $10.20474 /$-japs2.1.2

[11] K. E. N. T. Hortle, "A survey of the Barito river fishery near mount Muro, central Kalimantan, Indonesia," Tropical Limnology, vol. 3, pp. 15-27, 1995.
[12] M. W. Brogan, "Two methods of sampling fish larvae over reefs: A comparison from the gulf of California," Marine Biology, vol. 118, no. 1, pp. 33-44, 1994.

DOI: $10.1007 /$ bf00699217

[13] F. J. Hernandez and R. F. Shaw, "Comparison of plankton net and light trap methodologies for sampling larval and juvenile fishes at offshore petroleum platforms and a coastal jetty off Louisiana," in Fisheries, reefs and offshore development, D. R. Stanley and A. ScarboroughBull, Eds. Bethesda, MD: American Fisheries Society, 2003.

[14] W. J. Conover, "Practical nonparametric statistics," New York, NY: John Wiley, 1980.

[15] J. G. De Man, "On some species of the genus Palaemon Fabr. with descriptions of two new forms," Notes from the Leyden Museum, vol. 1, no. 3, pp. 165-184, 1879. DOI: $10.1111 /$ j.1096-3642.1904.tb00661.x

[16] C. Richards, F. J. Kutka, M. E. McDonald, G. W. Merrick and P. W. Devore, "Life history and temperature effects on catch of northern orconectid crayfish," Hydrobiologia, vol. 319, no. 2, pp. 111-118, 1996.

DOI: $10.1007 / \mathrm{bf00016879}$

[17] D. M. Holdich, "Biology of freshwater crayfish," Hoboken, NJ: Blackwell Science, 2002.

[18] M. Faller, I. Maguire and G. Klobučar, "A nnual activity of the noble crayfish (Astacus astacus) in the Orljava River (Croatia)," Bulletin Français de la Pêche et de la Pisciculture, no. 383, pp. 23-40, 2006.

DOI: $10.1051 / \mathrm{kmae}: 2006003$

[19] L. B. Holthuis, "Subfamily Palaemoninae, the Palaemonidae collected by the siboga and snellius expeditions with remarks on other species. I. the Decapoda of the Siboga Expedition Part X," Siboga Expeditie, no. 39, pp. $1-268$.

[20] A. Dimmock, I. Williamson and P. B. Mather, The influence of environment on the morphology of Macrobrachium australiense (Decapoda: Palaemonidae)," Aquaculture International, vol. 12, no. 4, pp. 435-456, 2004. DOI: $10.1023 /$ b:aqui.0000042140.48340.c8

[21] J.W. Short, "Systematics and biogeography of Australian Macrobrachium (Crustacea: Decapoda: Palaemonidae): with descriptions of other new freshwater Decapoda," Ph.D. dissertation, University of Queensland, St Lucia, Austraila, 2000. 
[22] G. K. Ahmadi and M. V. Archdale, "Mechanisms of phototaxis in American crayfish, procambarus clarkii (Girard, 1852) following different methods of trapping,"
Journal of Fisheries and Aquatic Sciences, vol. 3, no. 6, pp. $340-352,2008$. DOI: $10.3923 /$ jfas.2008.340.352

— This article does not have any appendix. — 